\title{
Genotype and Environment Interactions of Yields and Yield Components of Tea (Camellia sinensis) Cultivars in Kenya
}

\author{
Karl W. Nyabundi', P. Okinda Owuor ${ }^{2}$, Godfrey W. Netondo ${ }^{3}$, John K. Bore ${ }^{1}$ \\ ${ }^{1}$ Tea Research Institute, Kenya Agricultural and Livestock Research Organization, Kericho, Kenya \\ ${ }^{2}$ Department of Chemistry, School of Physical and Biological Sciences, Maseno University, Maseno, Kenya \\ ${ }^{3}$ Department of Botany, School of Physical and Biological Sciences, Maseno University, Maseno, Kenya \\ Email: nyabundikw@yahoo.com,pokindao@gmail.com,godfreynetondo@yahoo.co.uk, \\ Jnbore@yahoo.co.uk
}

Received 22 February 2016; accepted 22 April 2016; published 25 April 2016

Copyright (C) 2016 by authors and Scientific Research Publishing Inc.

This work is licensed under the Creative Commons Attribution International License (CC BY). http://creativecommons.org/licenses/by/4.0/

(c) $\underset{\mathrm{EY}}{\mathrm{E}}$ Open Access

\section{Abstract}

The tea crop provides income and employment to rural populations in many countries. In Kenya, tea, which is the leading export commodity crop, is grown in highlands east and west of the Rift Valley at altitudes ranging from $1300 \mathrm{~m}$ to $2700 \mathrm{~m}$ above mean sea level. Variable responses of tea genotypes to different environments have been demonstrated. This affects the growth, productivity, and quality of tea. However, most tea husbandry practices are uniform across tea growing regions leading to variations in yields and quality in the different environments. Understanding causes of variations in tea growth parameters and yields to varying environments is vital to optimizing husbandry practices for maximization of productivity. The responses in growth and yield parameters of clonal tea to locations of production and their contribution to yields were compared. A genotype $\times$ environment trial was conducted in three sites (Kangaita, Timbilil and Kipkebe). At each site, a trial comprising 20 cultivars was laid in a randomized complete design replicated 3 times. Yields, yield components and climatic data were collected then subjected to analysis of variance and regression analysis. There were significant $(p \leq 0.05)$ yield variations between clones and locations. Yields ranged from $5162 \mathrm{~kg} \mathrm{mt} / \mathrm{ha}$ on clone TRFK 303/577 at Kipkebe to $935 \mathrm{~kg} \mathrm{mt} / \mathrm{ha} /$ year on clone TRFK 7/3 in Kangaita, surpassing the maximum variation possible postulated in earlier studies. The responses of the tea yield components to weather parameters varied with genotypes and environments. Shoot growth rates in Timbilil $(r=0.476)$ ) and shoot density (Kangaita $(r=0.652)$ significantly $(p \leq 0.05)$ ) correlated with yields. Yield components and weather parameters contribution to the total yield also varied with locations. The variations demonstrated that not all yield components can be used universally as yield indicators for clonal selection in different locations. For optimal production, selected tea clones should therefore be tested before adoption for commercial planting in other locations. 
Keywords

Genotype, Environment, Weather Parameters, Yields, Yield Components

\section{Introduction}

Tea (Camellia sinensis (L). O. Kuntze), a perennial tree belonging to the Theacea family [1] [2], is managed as a low bush in continuous phase of vegetative growth. The crop provides income to farmers and employment to rural populations in many parts of the world. In Kenya, 377 million kilograms of made tea was produced from 171,916 Ha, in 2011, contributing to 4\% of GDP and 28\% of export earnings [3]. This was the highest export earnings from a single commodity and/or crop. The crop is grown in the high rainfall areas of Kenya, namely, foothills of the Aberdare Ranges and Mt Kenya, in the East of the Great Rift Valley and the Mau Ranges; Nandi, Kisii and Kakamega hills and slopes of Mt. Elgon in the West of the Rift Valley [4]. These areas range in altitude from $1300 \mathrm{~m}$ to $2700 \mathrm{~m}$ amsl [5] [6]. These areas lie almost along the equator, and shoots are harvested at 7 to 14 days intervals throughout the year [7]. However, yields [8] [9] and quality [10]-[12] are affected by fluctuations in weather factors within and between the years in any one location. Despite production close to the equator, the differences in geographical areas of production have been recorded to influence leaf nutrients levels [13]; growth rates [14]-[17], productivity [18]-[20], precursors of tea quality parameters [21]-[27] and black tea quality [26] [28]-[30] of tea. Despite use of same genotypes and management practices, yields and quality vary across the region. This suggests growth patterns in different genotypes may not be the same in the region. There is need to assess possible variations in growth patterns of different genotypes to determine whether yields can be predicted from the yields components in different locations.

Tea productivity [17] [31] [32] and quality [28] [33] varied with altitude and weather factors [11] [19]. There was yield reduction during dry and cool seasons [34] [35]. Indeed, the variations in yield performance of genotypes relative to each other and to the environment have been widely documented [18] [19] [36] with the phenomenon having been formulated in the Genotype by Environment $(G \times E)$ interaction concept [36]. However, the mechanisms causing the variations in yields are not well defined, especially since the level and extents of the variations change with genotypes. The understanding of the variations in responses in tea yield components with genotypes and locations may provide an explanation in the observed yield responses and lead to development of management practices that enhance productivity in different clones in different locations.

\section{Methodology}

\subsection{Experimental Treatments and Design}

The trial was set up in 2011 in three different tea growing geographic regions (Kangaita, Timbilil and Kipkebe) varying in proximity by between 45 and $245 \mathrm{Km}$ and altitudinal range differences of between 78 an $435 \mathrm{~m}$, namely (Table 1$)$. Slopes at all the sites are gentle to slightly sloping $(0 \%-15 \%)$. The trials were set up on plots of mature tea of the same age, planted in 1991 and comprising twenty clones namely; TRFK 6/8, TRFK 31/8, AHP S15/10, EPK TN14-3, BBK 35, TRFK 54/40, TRFK12/12, TRFK 12/19, TRFK 31/27, TRFK 11/26, TRFK 57/15, TRFK 7/3, TRFK 7/9, TRFK 56/89, STCK 5/3, TRFK 303/259, TRFK 303/577, TRFK 303/999, TRFK 303/1199 and TRFK 2X1/4 set in Randomized Complete Block design replicated three times at each site [18]. Each plot comprised of 20 bushes. The tea was managed under standard management practices in Kenya [5]. The yield components recorded were shoot density, dry weight, growth rate and water potential. The experiment was analysed as a $2 \times 3$ factorial 2 design with the clones and sites as the treatments.

\subsection{Data Sampling and Recording}

\subsubsection{Soil Characteristics}

Disturbed soil samples were collected from two sites from each trial location in approximate diagonal line across the experiment. The samples were collected in the dry season between January and March at depths of 0 20, 20 - 40, 40 - 60 [37] [38] using a Jarret auger. These were subjected to full chemical ( $\mathrm{pH}$ and nutrients) analysis and physical (soil texture) analysis for site characterization. 
Table 1. Study sites geographic location.

\begin{tabular}{cccc}
\hline Site & Location & Latitude & Longitude \\
\hline Timbilil & TRFK, Timbilil, Kericho & $0^{\circ} 22^{\prime} \mathrm{S}$ & $35^{\circ} 21^{\prime} \mathrm{E}$ \\
Kangaita & KTDA Kangaita Tea Farm, Kirinyaga & $0^{\circ} 30^{\prime} \mathrm{S}$ & $2180 \mathrm{~m}$ amsl \\
Kipkebe & Kipkebe Tea Company, Sotik, Nyamira & $0^{\circ} 39^{\circ} \mathrm{S}$ & $2100 \mathrm{~m}$ amsl \\
\hline
\end{tabular}

\subsubsection{Soil Chemical and Physical Analysis}

Fresh (un-dried) sub samples were subjected to analysis of soil $\mathrm{pH}$ by reading off a Jenway $3305 \mathrm{pH}$ meter. Nitrogen content was determined using the Kjeldahl method. For the mineral nutrient analysis, the soils were air dried, ground and sieved through a $2 \mathrm{~mm}$. sieve. The ground samples were then extracted using the Mehlich III method then analysed for nutrients $\mathrm{K}, \mathrm{P}, \mathrm{Ca}, \mathrm{Mg}, \mathrm{Mn}, \mathrm{Na}, \mathrm{Cu}, \mathrm{Fe}$ and $\mathrm{Zn}$ using a plasma atomic emission spectrophotometer (ICPE-9000, Shimandzu). Sub samples from the disturbed soil samples were subjected to particle size analysis using the pipette method [39], taking $63 \mu \mathrm{m}$ as the sand/silt boundary.

\subsubsection{Site Weather Characteristics}

Rainfall and temperature data were recorded from weather stations located at each trial site and accompanying meteorological data derived as follows; Rainfall was recorded daily using a standard rain gauge. Maximum, minimum, wet and dry bulb temperatures were recorded everyday at $09.00 \mathrm{~h}$ and $15.00 \mathrm{~h}$ local time using mercury in glass thermometers (Cassella (London) Ltd., UK). The relative humidity (RH\%) was derived from the wet and dry bulb temperature readings using relevant tables [40]. The wet and dry thermometer readings recorded as described above were used to derive saturated vapour pressure deficit (SVPD) using the formula. $\operatorname{SVPD}=e_{w}-e^{\prime}[41]$

Where:

$e^{\prime}=$ air vapour pressure $(\mathrm{mb})$ at $t^{\prime}$ (Table 94),

$e_{w}=$ air vapour pressure $(\mathrm{mb})$ at $t$ (Table 94$)$,

$t^{\prime}=$ dry bulb temperature $\left({ }^{\circ} \mathrm{C}\right)$,

$t$ = wet bulb temperature $\left({ }^{\circ} \mathrm{C}\right)$.

\subsubsection{Yield}

Green leaf comprising of mostly two leaves and a bud were plucked every 7 - 10 days and converted to made tea (mt) by multiplying by a factor of 0.225 [5].

\subsubsection{Shoot Density (SD), and Shoot Dry Weight (SDWT)}

Shoot density was determined by getting the mean of the number of mature harvestable shoots (two leaves and a bud) captured within a $0.25 \mathrm{~m}^{2}$ grid randomly thrown on to the plucking tables [42] of five randomly selected bushes at every plucking round. Shoots falling within the grid were plucked, weighed and counted. The shoots were then oven dried at $105^{\circ} \mathrm{C}$ for 48 hours and weighed. The SDWT was determined by dividing the dry weight by the number of shoots harvested.

\subsubsection{Shoot Growth Rate (SGR)}

The rate of shoot growth (millimetres per day $\left(\mathrm{mmd}^{-1}\right)$ ) was determined by tagging five shoots from each of three randomly selected bushes per plot. Growth was monitored by measuring the length from the tip of the auxiliary bud to the base every three days until the new shoot developed into a mature harvestable two leaves and a bud. The total length measured at each interval was divided by the number of days between two successive measurements to determine the growth rate $\left(\mathrm{mmd}^{-1}\right)$.

\subsubsection{Shoot/Xylem Water Potential (SWP)}

The xylem water potential of pluckable shoots was measured between 11.00 am and $2.00 \mathrm{pm}$, using the pressure chamber technique [43]. Three shoots each from five randomly selected bushes per plot were cut and measured one by one on each plucking day. The shoots were and transferred to the site of the pressure chamber where one centimetre was cut off the stalk and the shoot immediately inserted into the gas chamber. The key of the com- 
pressed nitrogen gas turned on until the first gas bubbles were released from the cut shoot stalk surface and the pressure reading taken. These measurements were taken twice a season and averaged to get the season mean.

\subsection{Data Analysis}

The data collected was subjected to analysis of variance (ANOVA) using MSTAT-C (Version 2.10) statistical package, as a factorial two design, with clone (genotype) as the main factor and location as the second factor. Correlations between yield and yield components and weather parameters were done using SPSS (Version 17.0) statistical software.

\section{Results and Discussion}

\subsection{Soil Variability and Suitability}

The soil characteristics of the experimental sites are given in Table 2 and Table 3 . The textural properties of the soils showed variations, with Kangaita soils having coarser texture than Timbilil and Kipkebe soils. Kangaita had higher sand and lower clay contents than the other two sites, which were similar. The porosity ranged from $38 \%$ to $56 \%$, with little variation between the sites. The soils from all the sites were of volcanic origin [44]. Tea is grown in soils of varying texture and in soils with clay content as high as $83 \%$ in Kenya and as low as $1.7 \%$ in Taiwan [45]. The soils in this study fell within these ranges and were similar to those observed in Kericho [46],

Table 2. Soil physical characteristics of the trial sites.

\begin{tabular}{|c|c|c|c|c|c|c|c|}
\hline Location & Depth & \% sand & \% clay & $\%$ silt & Textural class & $\%$ porosity & Soil description ${ }^{*}$ \\
\hline \multirow{3}{*}{ Timbilil } & $0-20$ & 41.37 & 49.75 & 10.96 & Clay & 37.56 & \multirow{3}{*}{$\begin{array}{l}\text { Volcanic dark red (10R } 3 / 2) \text {, deep friable } \\
\text { clays with a dusky red }(2.5 \mathrm{YR} 3 / 6) \text { top } \\
\text { soil }(0-0.1 \mathrm{~m}) \text {, with Kaolinite as the } \\
\text { predominant , classified as humicnitosols }\end{array}$} \\
\hline & $20-40$ & 42.15 & 44.13 & 13.28 & Clay & 45.22 & \\
\hline & $40-60$ & 38.08 & 48.36 & 15.57 & Clay & 47.00 & \\
\hline \multirow{3}{*}{ Kangaita } & $0-20$ & 76.20 & 13.44 & 10.36 & Sandy loam & 42.00 & \multirow{3}{*}{$\begin{array}{l}\text { Volcanic reddish brown to dark brown, } \\
\text { extremely deep, friable and slightly smeary } \\
\text { clay with acid humic top soils, classed } \\
\text { as ando-humicnitosols }\end{array}$} \\
\hline & $20-40$ & 71.00 & 18.11 & 10.89 & Sandy loam & 41.00 & \\
\hline & $40-60$ & 62.65 & 24.72 & 12.63 & Sandy loam & 55.67 & \\
\hline \multirow{3}{*}{ Kipkebe } & $0-20$ & 30.62 & 57.35 & 14.73 & Clay & 37.74 & \multirow{3}{*}{$\begin{array}{l}\text { Dark reddish brown (2.5YR 3/4), deep to } \\
\text { very deep, with friable and slightly smeary top } \\
\text { soils, which were developed on acid igneous } \\
\text { rock, classed as andoluvic phaeozems }\end{array}$} \\
\hline & $20-40$ & 47.14 & 42.63 & 12.17 & Clay & 39.63 & \\
\hline & $40-60$ & 46.31 & 38.35 & 16.01 & Clay & 46.44 & \\
\hline
\end{tabular}

*Soil description after Jaetzold and Schmidt, 2010.

Table 3. Soil chemical characteristics of trial sites.

\begin{tabular}{|c|c|c|c|c|c|c|c|c|c|c|c|c|}
\hline Location & Depth. & $\mathrm{pH}$ & $\begin{array}{c}\mathrm{N} \\
(\mathrm{ppm})\end{array}$ & $\begin{array}{c}\mathrm{P} \\
(\mathrm{ppm})\end{array}$ & $\begin{array}{c}\mathrm{K} \\
(\mathrm{ppm})\end{array}$ & $\begin{array}{c}\mathrm{Ca} \\
(\mathrm{ppm})\end{array}$ & $\begin{array}{c}\mathrm{Mn} \\
(\mathrm{ppm})\end{array}$ & $\begin{array}{c}\mathrm{Mg} \\
(\mathrm{ppm})\end{array}$ & $\begin{array}{c}\mathrm{Na} \\
(\mathrm{ppm})\end{array}$ & $\begin{array}{c}\mathrm{Cu} \\
(\mathrm{ppm})\end{array}$ & $\begin{array}{c}\text { Fe } \\
(\mathrm{ppm})\end{array}$ & $\begin{array}{c}\mathrm{Zn} \\
(\mathrm{ppm})\end{array}$ \\
\hline \multirow{3}{*}{ Timbilil } & $0-20$ & 3.9 & 57.5 & 19.1 & 157.8 & 264.6 & 196.9 & 69.4 & 67.4 & 19.0 & 70.4 & 32.4 \\
\hline & $20-40$ & 3.6 & 47.5 & 31.8 & 187.7 & 315.1 & 314.9 & 73.3 & 70.1 & 25.0 & 96.3 & 41.9 \\
\hline & $40-60$ & 3.8 & 45.0 & 23.4 & 181.4 & 295.1 & 243.5 & 70.9 & 68.1 & 19.5 & 77.7 & 34.4 \\
\hline \multirow{3}{*}{ Kangaita } & $0-20$ & 3.6 & 29.5 & 27.6 & 669.6 & 133.6 & 27.4 & 23.4 & 93.8 & 2.5 & 145.0 & 3.2 \\
\hline & $20-40$ & 3.6 & 33.5 & 20.2 & 349.7 & 120.1 & 23.3 & 21.6 & 94.8 & 2.4 & 117.2 & 3.6 \\
\hline & $40-60$ & 3.7 & 58.5 & 21.5 & 235.8 & 99.8 & 22.1 & 19.1 & 88.3 & 2.3 & 113.4 & 3.5 \\
\hline \multirow{3}{*}{ Kipkebe } & $0-20$ & 4.0 & 49.5 & 12.8 & 189.1 & 551.9 & 530.1 & 345.1 & 151.3 & 7.1 & 159.2 & 4.6 \\
\hline & $20-40$ & 3.4 & 43.0 & 14.7 & 190.7 & 520.4 & 767.2 & 176.3 & 138.5 & 7.1 & 155.0 & 7.2 \\
\hline & $40-60$ & 3.8 & 42.5 & 12.7 & 198.0 & 563.7 & 591.1 & 281.1 & 142.9 & 7.2 & 155.3 & 8.0 \\
\hline
\end{tabular}


and sandy loam in Kangaita in Kangaita and Nyambene [47]. These results demonstrate the ability of tea to grow in a wide variety of soil textural types. The $\mathrm{pH}$ of the soils from the three sites ranged from 4.0 to 3.4 but were predominantly lower than 4.0 (Table 3). There was very little variation in the soil $\mathrm{pH}$ between the sites. Tea grows in soils of optimal pH of 4.0 to 6.0 [5], but can grow in pH below 4.0 [45]. Indeed, optimal growth of tea had been reported at $\mathrm{pH}$ ranges between 3.8 and 5.7 in land newly cleared from primary, secondary forests and tree plantations [46] [47]. The soil mineral contents (Table 3) were within the ranges observed in the major tea growing areas [45]. The soil nitrogen contents were adequate for tea growth. However, site variations were evident with Kangaita recording higher nitrogen levels than the other locations. These results demonstrate that the soils were suitable for tea growing. Thus, constraints or low tea productivity at any of the sites would be due to other factors. These results demonstrate that though tea can be successfully and commercially grown in a wide variety of soil types, the variations in soil types contribute significantly to locational yield variations. [46] [48] observed soil differences between sites and even significantly big differences between sites across East Africa tea growing regions. He observed that soil water deficits, compaction and soil water deficits could restrict productivity of tea in different locations. Indeed results of soil water potential which is directly related to plant water status shows significant site variations in this study.

\subsection{Weather and Geographical Locations}

The weather components from the three trial sites during the duration of the trial are shown in Table 6. There were noticeable differences between the sites in all the weather parameters measured and derived (rainfall, rain days, ambient temperatures, relative humidity and vapour pressure deficit).

\subsection{Temperatures}

Mean monthly temperatures generally rose with declining altitude from Timbilil to Kipkebe (Table 1 and Table 4). However, Kipkebe had the highest mean ambient temperatures but mean Kangaita and Timbilil temperatures were similar despite the difference in altitude (Table 1). This was due the close proximity of Kangaita site to the Mt. Kenya and the Mt Kenya Forest which lowered mean daily temperatures. The mean temperature difference between Kangaita and Timbilil was only $1^{\circ} \mathrm{C}$ while between Kipkebe and Timbilil and Kipkebe and Kangaita were $3^{\circ} \mathrm{C}$ and $4^{\circ} \mathrm{C}$, respectively. These results were similar to those obtained earlier [17] where temperature difference between locations at high altitude (over $2000 \mathrm{~m}$ ) was lower than those between high and lower altitude (below $2000 \mathrm{~m}$ ) locations. Therefore the two locations, Kangaita and Timbilil, both lying above $2000 \mathrm{~m}$ were similar in terms of mean annual temperatures despite their altitudinal difference, but significantly different from the low altitude Kipkebe site.

\subsection{Rainfall}

The rainfall pattern in Kangaita was bimodal with peaks in April-May and October-November, separated by cold and hot dry seasons from June to August and January to March, respectively. Rainfall pattern in Timbilil was unimodal with rains starting in April and continuing up to December. In Kipkebe the rainfall was weakly bimodal with peaks in April to July and in December (Table 4) as had been reported earlier for Kericho [49]. Total rainfall declined with decreasing altitude from Timbilil to Kipkebe (Table 1 and Table 4). However, these relationships were not significant. Timbilil and Kipkebe had more rain days during the year but were drier in the January-March season, with no rain in the month of January. These seasonal variations are likely to impact on total annual yields variations between the sites.

\subsection{Relative Humidity (Rh) and Vapour Pressure Deficit (VPD)}

Relative humidity (Rh) and vapour pressure deficit (VPD) also showed variations between sites. Mean monthly relative humidity increased from high to low altitude. The high humidity recorded at Kipkebe was attributed to its closer proximity to the Lake Victoria. Monthly VPD was highest in Timbilil and lowest in Kangaita. Highest VPDs were recorded during the January March period at all sites but was highest at Timbilil. This suggests more severe drought in Timbilil than at Kipkebe and Kangaita. Seasonal variations of the weather parameters within and between sites were also evident. Soil water deficits are determined by ambient temperatures and humidity, similar to shoot water potential (SWP). Atmospheric humidity is inversely related to vapour pressure 
Table 4. Monthly weather parameters at all the trial sites, Jan-Dec 2012.

\begin{tabular}{|c|c|c|c|c|c|c|c|c|c|c|c|c|c|c|c|}
\hline & \multicolumn{5}{|c|}{ TIMBILIL (0²2'S) } & \multicolumn{5}{|c|}{ KANGAITA $\left(0^{\circ} 30^{\prime} \mathrm{S}\right)$} & \multicolumn{5}{|c|}{ KIPKEBE $\left(0^{\circ} 39^{\prime S}\right)$} \\
\hline & $\begin{array}{l}\text { Temp } \\
\left({ }^{\circ} \mathrm{C}\right)\end{array}$ & $\begin{array}{l}\text { Rain } \\
(\mathrm{mm})\end{array}$ & $\begin{array}{l}\text { Rdays } \\
\text { (d) }\end{array}$ & $\begin{array}{l}\text { Rh } \\
(\%)\end{array}$ & $\begin{array}{c}\text { Vpd } \\
(\mathrm{kPa})\end{array}$ & $\begin{array}{l}\text { Temp } \\
\left({ }^{\circ} \mathrm{C}\right)\end{array}$ & $\begin{array}{l}\text { Rain } \\
(\mathrm{mm})\end{array}$ & $\begin{array}{l}\text { Rdays } \\
\text { (d) }\end{array}$ & $\begin{array}{l}\mathrm{Rh} \\
(\%)\end{array}$ & $\begin{array}{c}\text { Vpd } \\
(\mathrm{kPa})\end{array}$ & $\begin{array}{c}\text { Temp } \\
\left({ }^{\circ} \mathrm{C}\right)\end{array}$ & $\begin{array}{l}\text { Rain } \\
(\mathrm{mm})\end{array}$ & $\begin{array}{l}\text { Rdays } \\
\text { (d) }\end{array}$ & $\begin{array}{l}\mathrm{Rh} \\
(\%)\end{array}$ & $\begin{array}{r}\text { Vpd } \\
(\mathrm{kPa})\end{array}$ \\
\hline Jan & 16.7 & 0.0 & 0.0 & 46 & 10.33 & 16.3 & 17.2 & 3.0 & 55 & 8.91 & 19.9 & 0.5 & 0.0 & 64 & 7.82 \\
\hline Feb & 17.7 & 26.8 & 7.0 & 38 & 11.41 & 15.3 & 19.7 & 4.0 & 55 & 8.56 & 20.1 & 82.9 & 11.0 & 73 & 5.97 \\
\hline Mar & 18.0 & 27.7 & 6.0 & 48 & 10.11 & 17.1 & 40.3 & 3.0 & 55 & 8.18 & 19.4 & 50.1 & 7.0 & 73 & 5.9 \\
\hline Apr & 15.3 & 398.4 & 25.0 & 71 & 5.65 & 16.2 & 449.6 & 23.0 & 80 & 3.93 & 19.5 & 514.4 & 26.0 & 80 & 3.34 \\
\hline May & 16.4 & 391.1 & 24.0 & 80 & 3.62 & 16.4 & 692.0 & 25.0 & 80 & 3.49 & 19.6 & 249.4 & 24.0 & 80 & 3.53 \\
\hline Jun & 16.0 & 226.9 & 20.0 & 80 & 3.34 & 14.8 & 89.4 & 16.0 & 89 & 1.97 & 18.6 & 178.3 & 20.0 & 90 & 2.58 \\
\hline Jul & 15.7 & 160.9 & 13.0 & 79 & 3.38 & 13.3 & 49.1 & 16.0 & 88 & 1.39 & 18.6 & 122.6 & 10.0 & 85 & 3.07 \\
\hline Aug & 16.1 & 298.9 & 18.0 & 70 & 4.51 & 13.6 & 190.5 & 14.0 & 78 & 2.68 & 18.9 & 97.7 & 11.0 & 80 & 3.45 \\
\hline Sept & 15.7 & 239.1 & 24.0 & 80 & 4.9 & 16.5 & 121.8 & 8.0 & 78 & 3.1 & 17.8 & 194.5 & 17.0 & 81 & 3.62 \\
\hline Oct & 16.9 & 269.4 & 24.0 & 63 & 6.63 & 15.4 & 325.0 & 11.0 & 80 & 3.58 & 20.5 & 99.3 & 16.0 & 76 & 4.96 \\
\hline Nov & 16.9 & 227.6 & 22.0 & 62 & 6.54 & 15.5 & 234.1 & 13.0 & 80 & 3.25 & 19.7 & 97.1 & 15.0 & 80 & 3.48 \\
\hline Dec & 16.4 & 172.3 & 15.0 & 62 & 6.43 & 15.1 & 169.6 & 17.0 & 71 & 4.81 & 19.7 & 261.6 & 17.0 & 80 & 3.44 \\
\hline Total & & 2439 & 198 & & & & 2398 & 153 & & & & 1948 & 174 & & \\
\hline Mean & 16.5 & & & 68.3 & 8.0 & 15.4 & & & 54.8 & 5.3 & 19.3 & & & 76.5 & 5.9 \\
\hline
\end{tabular}

deficits [50] [51]. An inverse linear relationship between VPD and SWP in tea has been reported [8] [52] [53], although the SWP of tea shoots were more closely related to VPD than to soil moisture [8] [19] reported variations in soil water deficits between sites in Kericho, which affected the difference in yield variations.

\subsection{Yield Components}

The recorded shoot growth rates, shoot dry weights, shoot densities and shoot water potentials and their rankings are shown in Table 5 and Table 6.

\subsection{Shoot Growth Rate}

The shoot growth rates (Table 5) in Kangaita and Timbilil were similar, but lower $(p \leq 0.001)$ than that of Kipkebe. Plant growth rates at the two sites followed the locational temperature patterns (Table 4) and were thus expected to be similar or insignificantly different since temperature is a major determinant of growth as reported in previous studies [15]-[17]. The clones $x$ sites interactions were also significant $(p \leq 0.001)$ demonstrating the shoot growth rates of the various cultivars were not responding in similar patterns in all sites. There was a positive response of shoot growth rates to temperature but an inverse response to vapour pressure deficit across three locations (Table 5 and Table 6). Clonal variations in shoot growth rates varied both within and across locations. Indeed, variations in clonal growth rates were not consistent across all sites as the shoot growth rate rankings showed variation with location (Table 6). Some clones however, were ranked in the same quartile across two or three locations. The differences between the highest and lowest clonal growth rates also varied with location with the highest $(0.56 \mathrm{~mm} /$ day $)$ in Kipkebe and the lowest in Kangaita $(0.15 \mathrm{~mm} /$ day). Similar results were reported in earlier findings of clonal variation within one location [54] [55] across seasons [56] and across locations [15] [17] [18]. Shoot growth rate will vary with genotype and the genotypic variation will also vary from one location to the other. [8] opined that changes in shoot growth rates could be explained by the inherent effects of temperature and relative humidity, which varied across seasons. Temperature and relative humidity indeed, determine the prevailing vapour pressure deficits in any one location. The findings by [8] therefore explain the relations between shoot growth rates and saturated vapour pressure deficits observed in this 
study. Vapour pressure deficits are therefore a major weather parameter other than temperature that determines the shoot growth rate of the tea plant.

\subsection{Shoot Dry Weight and Shoot Density}

Shoot densities showed significant $(\mathrm{p} \leq 0.001)$ variations due to genotype and location. The genotype $\mathrm{x}$ location interactions was also significant $(\mathrm{p} \leq 0.001)$. Whereas shoot dry weights varied $(\mathrm{p} \leq 0.001)$ between sites there was no apparent response to temperature or vapour pressure deficit. The shoot densities variation ( $\mathrm{p} \leq 0.001)$ due to location however, correlated positively with vapour pressure deficits but not temperature, across the sites. The highest mean shoot density was recorded in Kangaita $\left(119\right.$ shoots $\left.\mathrm{m}^{-2}\right)$ and lowest at Timbilil (32 shoots $\mathrm{m}^{-2}$ ). [15] reported varying clonal response of shoot density with altitude.

Table 5. Effect of geographical location and genotype on yield components.

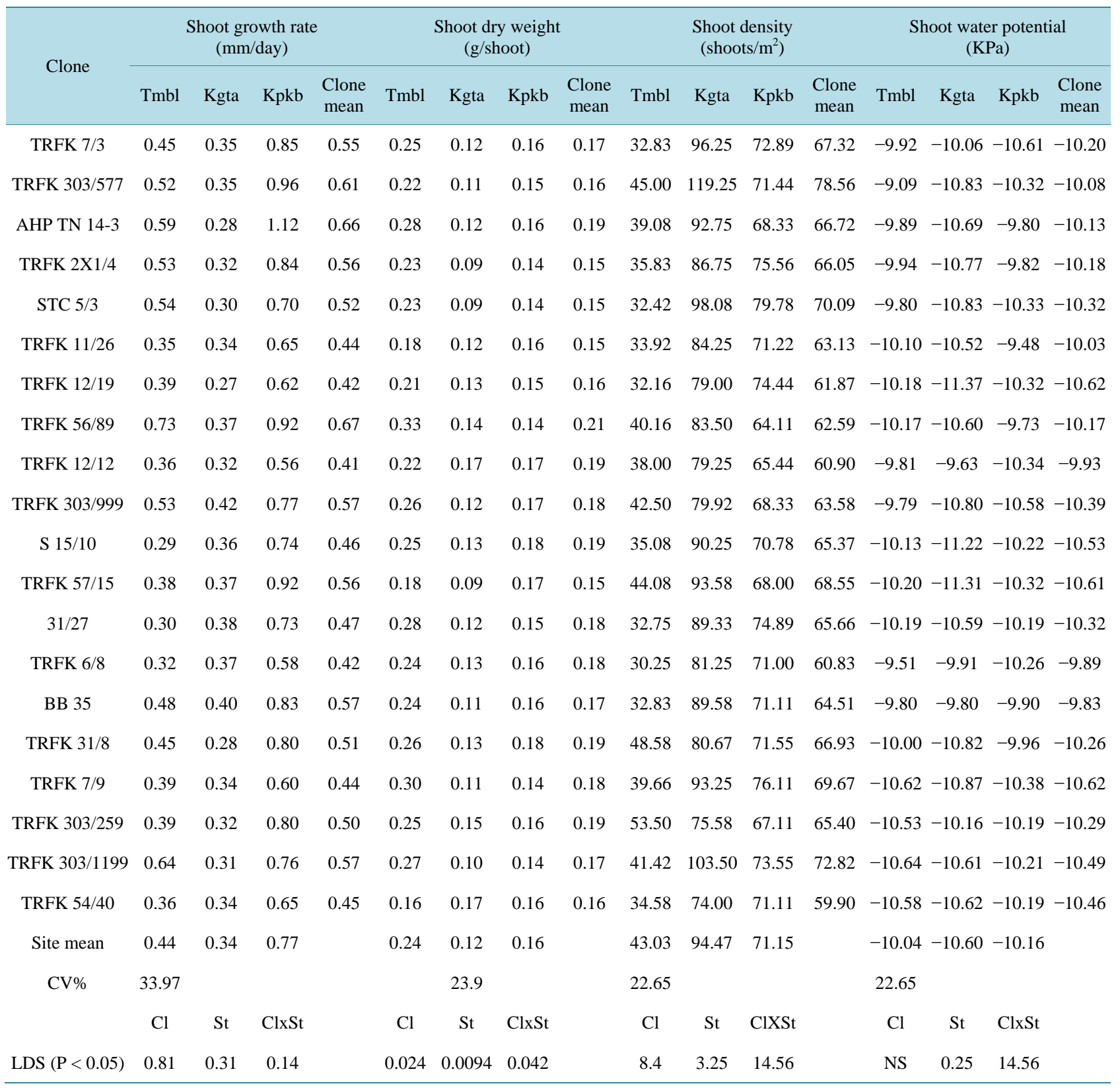

$\mathrm{Cl}=$ clone; St. = site. 
Table 6. Effect of geographical location on ranking of genotype yield and components.

\begin{tabular}{|c|c|c|c|c|c|c|c|c|c|c|c|c|c|c|c|}
\hline & \multirow{2}{*}{ Tmbl } & \multicolumn{2}{|c|}{$\begin{array}{l}\text { Annual } \\
\text { yields }\end{array}$} & \multirow{2}{*}{ Tmbl } & \multicolumn{2}{|c|}{$\begin{array}{l}\text { Shoot growth } \\
\text { rate }\end{array}$} & \multirow{2}{*}{ Tmbl } & \multicolumn{2}{|c|}{$\begin{array}{l}\text { Shoot dry } \\
\text { weight }\end{array}$} & \multirow{2}{*}{ Tmbl } & \multicolumn{2}{|c|}{$\begin{array}{l}\text { Shoot } \\
\text { density }\end{array}$} & \multirow{2}{*}{ Tmbl } & \multicolumn{2}{|c|}{$\begin{array}{c}\text { Shoot water } \\
\text { potential }\end{array}$} \\
\hline & & Kgta & Kpkb & & Kgta & Kpkb & & Kgta & Kpkb & & Kgta & Kpkb & & Kgta & Kpkb \\
\hline TRFK 7/3 & 19 & 11 & 14 & 9 & 8 & 5 & 8 & 9 & 6 & 15 & 4 & 7 & 8 & 4 & 20 \\
\hline TRFK 303/577 & 1 & 4 & 1 & 7 & 9 & 2 & 15 & 14 & 13 & 3 & 1 & 9 & 1 & 15 & 13 \\
\hline TRFK 2X1/4 & 20 & 16 & 18 & 5 & 13 & 6 & 13 & 18 & 16 & 11 & 11 & 33 & 9 & 12 & 4 \\
\hline STC 5/3 & 16 & 9 & 8 & 4 & 17 & 14 & 14 & 19 & 17 & 18 & 3 & 1 & 4 & 16 & 16 \\
\hline TRFK 11/26 & 11 & 14 & 13 & 17 & 10 & 15 & 18 & 11 & 8 & 14 & 12 & 10 & 11 & 6 & 1 \\
\hline TRFK 12/19 & 13 & 12 & 17 & 11 & 20 & 17 & 17 & 5 & 14 & 19 & 18 & 5 & 14 & 20 & 14 \\
\hline TRFK 12/12 & 6 & 17 & 12 & 15 & 14 & 20 & 16 & 1 & 3 & 10 & 17 & 19 & 6 & 1 & 17 \\
\hline TRFK 303/999 & 8 & 5 & 16 & 6 & 1 & 10 & 6 & 12 & 4 & 5 & 16 & 16 & 3 & 13 & 19 \\
\hline S $15 / 10$ & 7 & 13 & 9 & 20 & 7 & 12 & 9 & 6 & 1 & 12 & 8 & 14 & 12 & 18 & 11 \\
\hline TRFK 57/15 & 18 & 8 & 20 & 14 & 5 & 4 & 19 & 20 & 5 & 4 & 5 & 17 & 16 & 19 & 15 \\
\hline TRFK 31/27 & 12 & 10 & 19 & 19 & 3 & 13 & 4 & 13 & 15 & 17 & 10 & 4 & 15 & 7 & 7 \\
\hline TRFK 6/8 & 17 & 15 & 11 & 18 & 6 & 19 & 11 & 7 & 9 & 20 & 14 & 13 & 2 & 3 & 12 \\
\hline BB 35 & 9 & 18 & 3 & 8 & 2 & 7 & 12 & 15 & 10 & 16 & 9 & 11 & 5 & 2 & 5 \\
\hline TRFK 31/8 & 15 & 7 & 10 & 10 & 19 & 8 & 7 & 8 & 2 & 2 & 15 & 8 & 10 & 14 & 6 \\
\hline TRFK 7/9 & 14 & 19 & 6 & 12 & 11 & 18 & 2 & 16 & 19 & 8 & 6 & 2 & 19 & 17 & 18 \\
\hline TRFK 303/1199 & 2 & 3 & 5 & 2 & 16 & 11 & 5 & 17 & 20 & 6 & 2 & 6 & 20 & 9 & 10 \\
\hline TRFK 54/40 & 10 & 20 & 15 & 16 & 12 & 16 & 20 & 2 & 12 & 13 & 20 & 12 & 18 & 10 & 9 \\
\hline
\end{tabular}

\subsection{Shoot Water Potential}

Shoot water potential showed no variation between genotypes but showed highly significant $(\mathrm{p} \leq 0.001)$ site variations. The changes followed the pattern of vapour pressure deficits across the sites (Table 4). Indeed, [7] demonstrated that shoot water potential of tea shoots were more closely related to vapour pressure deficits than to soil moisture. Shoot water potential influences shoot growth by determining the cellular turgidity required for cell expansion [35]. These findings suggest a threshold of plant water status for tea shoot survival and growth, and this does not vary with genotypes but varies with location. The threshold for plant water status is therefore determined by location weather attributes that dictate the vapour pressure deficit. Selection for optimal yield performance across locations should therefore take cognisance of prevailing vapour pressure deficits as the shoot growth rates determine the potential yields attainable [35]. Management practices to optimise yields may also yield better results if measures to alleviate vapour pressure deficits are effected.

\subsection{Annual Yields}

There were significant $(\mathrm{p} \leq 0.001)$ genotypic and site differences in annual yields (Table 7). The clones $\mathrm{x}$ site interactions were also significant $(\mathrm{p} \leq 0.001)$. There were significant yield variations due to genotype. The genotypic variations were manifested in all locations and the extents of the variations changed from location to location. Clonal mean yields were lowest $(\mathrm{p} \leq 0.05)$ in Timbilil and highest in Kipkebe. This yield trend mimicked the locational temperature patterns (Table 4). 
Table 7. Effect of geographical location and genotype on annual yields $\left(\mathrm{kg} \cdot \mathrm{ha}^{-1}\right)$ and their rankings.

\begin{tabular}{|c|c|c|c|c|c|c|c|}
\hline & \multicolumn{3}{|c|}{ Yields } & \multirow{2}{*}{ Mean } & \multicolumn{3}{|c|}{ Yield ranking } \\
\hline & Timbilil & Kangaita & Kipkebe & & Timbilil & Kangaita & Kipkebe \\
\hline TRFK 7/3 & 1520 & 935 & 3349 & 1934 & $20^{+}$ & $20^{+}$ & $16^{+}$ \\
\hline TRFK 303/577 & 3244 & 2408 & 4583 & 3412 & $2^{*}$ & $1^{*}$ & $2^{*}$ \\
\hline TN 14-3 & 2663 & 1950 & 4037 & 2883 & $4^{*}$ & $2^{*}$ & $4^{*}$ \\
\hline TRFK 2X1/4 & 2083 & 1218 & 3932 & 2411 & 7 & 14 & 6 \\
\hline STC 5/3 & 1754 & 1003 & 3431 & 2063 & $17^{\#}$ & $18^{\#}$ & 10 \\
\hline TRFK 11/26 & 1596 & 1272 & 3352 & 2073 & $19^{\#}$ & 11 & $15^{\#}$ \\
\hline TRFK 12/19 & 2278 & 1181 & 3689 & 2383 & 6 & 15 & 8 \\
\hline TRFK 56/89 & 2054 & 1234 & 3468 & 2252 & 9 & 13 & 9 \\
\hline TRFK 12/12 & 2051 & 1504 & 3304 & 2286 & 10 & 6 & 17 \\
\hline TRFK 303/999 & 2014 & 1306 & 3077 & 2132 & 11 & 9 & 19 \\
\hline S $15 / 10$ & 2413 & 1179 & 3400 & 2331 & 5 & 16 & 12 \\
\hline TRFK 57/15 & 1851 & 1434 & 3410 & 2232 & 16 & 8 & 11 \\
\hline TRFK 31/27 & 1958 & 1536 & 2752 & 2082 & 13 & 4 & 20 \\
\hline TRFK 6/8 & 1710 & 1045 & 3087 & 1947 & $18^{+}$ & $17^{+}$ & $18^{+}$ \\
\hline BB 35 & 2685 & 942 & 3863 & 2497 & 3 & 19 & 7 \\
\hline TRFK 31/8 & 1878 & 1444 & 3989 & 2437 & 14 & 7 & 5 \\
\hline TRFK 7/9 & 1856 & 1242 & 3399 & 2166 & 15 & 12 & 13 \\
\hline TRFK 303/259 & 1981 & 1277 & 4234 & 2497 & 12 & 10 & 3 \\
\hline TRFK 303/1199 & 3671 & 1903 & 5162 & 3579 & $1^{*}$ & $3^{*}$ & $1^{*}$ \\
\hline $54 / 40$ & 2060 & 1510 & 3369 & 2313 & 8 & 5 & 14 \\
\hline Ste Mean & 2166 & 1376 & 3644 & & & & \\
\hline \multirow[t]{2}{*}{ CV\% } & 14.77 & & & & & & \\
\hline & Clone & Site & $\mathrm{CxS}$ & & & & \\
\hline $\operatorname{LSD}(0.05)$ & 654 & 253 & 1134 & & & & \\
\hline
\end{tabular}

${ }^{*}$ Consistent superior performance (1st quartile) across all three locations; ${ }^{*}$ Consistent poor performance (4th quartile) across two locations; ${ }^{+}$Poor performance (4th quartile) across all three locations.

The clones and sites interaction were illustrated in the variations in clonal yield rankings between sites (Table 9); clone TRFK 303/577 recorded highest yield (5162 kg mt/ha) at Kipkebe while TRFK 7/3 recorded the lowest yield (763 kg mt/ha) at Timbilil. All clones recorded highest yields at Kipkebe. There were also variations in yield rankings among the clones between sites. Yield differences between the highest and lowest yielding clones also varied between sites. These differences were highest in Timbilil at $2410 \mathrm{~kg}$ and lowest in Kipkebe at 1473 $\mathrm{kg}$. This phenomenon elucidated the variation in genotype yield response to the different environments. Clonal yield rankings showed clonal yield stability across only two environments in clones TRFK 303/577, TRFK 12/19, AHP S15/10 and TRFK 54/40.

Some clones showed consistent good yield performance across all environments, falling in the 1st quartile in all locations. However, consistent inferior yield performance (4th quartile) across all three locations was exhibited by only two clones (TRFK 7/3 and 6/8). Similarly, consistent poor performance under low temperature conditions (Kangaita and Timbilil) was exhibited by only one clone (STC 5/3). One clone, TRFK 11/26 showed consistent poor performance across two temperature regimes of Timbilil and Kipkebe. Majority of the clones did 
not show any consistent yield correlations with locations. These results demonstrate the variability in clonal yield response to environment as earlier reported, on yields in Kenya [14] [17] [18], Tanzania [56], across East Africa region [58] in Sri Lanka [35] and on catechin content [21] [22]. However, the results could not be extrapolated to other regions unless the differences in yield were related to specific environmental variables such as soil water deficit (SWD) and temperature [59].

The differences between the three geographical locations can be explained in terms of the weather differences (Table 4), as had been observed in earlier studies [17]-[19]. The earlier reported studies however, involved sites around Kericho, within a radius of $20 \mathrm{Km}$ [16] [18] and two only sites, with different weather patterns (Kericho and Kangaita) [18]. The findings from this study replicate findings reported from single sites and also from multiple sites above. Clonal yield variations were observed to occur under different weather patterns (Kericho and Kangaita) and different temperature regimes (Kericho/Kangaita and Sotik). This means that despite close similarities in weather parameters between locations, tea genotypes will respond differently in the locations. Hence, different clones with similar performance under the same management in one site will require different management options to optimize yields in a separate location. [48] made similar observations. Therefore, importing clones selected for high yield in a different location may not optimise yields.

\subsection{Shoot Components and Yield Interactions}

Yield correlations showed that yield components' correlation to yields varied with environment (Table 8). The magnitude of the correlation varied with locations. Just as [8] observed that shoot density and shoot weights may be important in determining yields between clones in one site, this does not apply to different clones in different geographical locations. The correlations showed that different yield components may be important in determining yields in varying locations. The magnitude of the correlations between yields and growth components varied with locations. Significant relationship between shoot growth rate and yield was observed in Timbilil $(r=0.476$, $\mathrm{p} \leq 0.05)$ but not at Kipkebe $(r=0.384)$ and Kangaita $(r=0.001)$ while shoot density showed significant relationship in Kangaita $(r=0.652, \mathrm{p} \leq 0.05)$ (Table 8). Observations by [8] that shoot density and shoot weights are important in determining yields between clones concurred with observation from Timbilil only. Shoot dry weights and shoot water potentials showed no significant correlation to yield. Thus the relationship is not universal. These results imply variation of yield components contribution to yield amongst genotypes. Yield selection using yield components may be genotype specific and therefore weighting of the components may need to be considered during genotype selection.

In Kangaita, all yield components in the model were additive to yield (Equation (1)). In Kipkebe and Timbilil however, the high temperatures resulted in low plant shoot water potentials thereby reducing potential yields (Equations (2) and (3)). The negative shoot water potential was attributed to the prolonged droughts experienced in the two locations during the period of the study.

$$
\begin{gathered}
Y=-4618+10140 S+33.66 D+10140 W+134.7 P \\
Y=2181+2204 S+18.78 D+4758 W-167.87 P \\
Y=3428+2117 S-38.71 D+370 W-438.78 P
\end{gathered}
$$

where:

$$
\begin{aligned}
& S=\text { Shoot growth rate, } \\
& D=\text { Shoot density, } \\
& W=\text { Shoot dry weight, } \\
& P=\text { Shoot water potential. }
\end{aligned}
$$

Table 8. Effect of geographical location on relationship (r) between yields and yield components.

\begin{tabular}{cccccc}
\hline Location & & Sgr & Sd & Sdwt & Swp \\
\hline Kangaita & Yield & 0.001 & $0.652^{* *}$ & -0.065 & 0.115 \\
Kipkebe & Yield & 0.384 & -0.072 & 0.029 & -0.137 \\
Timbilil & Yield & $0.476^{*}$ & 0.396 & 0.231 & -0.219 \\
\hline
\end{tabular}

$\mathrm{N}=20,{ }^{* *}$ Correlation is significant at the 0.01 level; ${ }^{*}$ Correlation is significant at the 0.05 level; Sgr = Shoot growth rate; Sd = Shoot density; Sdwt = Shoot dry weight; Swp = Shoot water potential. 
Stepwise regression further revealed the yield components that significantly contributed to yields in each location. In Kangaita, shoot density was significant $(r=0.652 ; 0.425)$ as was the combination of shoot density and shoot dry weight $(\mathrm{r}=0.792 ; 0.628)$. In Timbilil only shoot growth rate was significant in determining yield $(\mathrm{r}=$ 0.476; 0.226). For Kipkebe, the regression could not be generated, suggesting that at that location, the individual and combination of yield components do not met the significant threshold to determine yield. This therefore suggests that at Kipkebe all yield components may combine equally to determine potential yields. [57] reported similar results from 4 clones in Timbilil in Kericho and further reported that effects of individual components were highly varied and did not relate with potential clonal tea yields.

[17] showed a relationship between shoot sizes and shoot mass. The size of shoots harvested is an important factor in determining yield [59] [60]. The regression models above indicate the importance of shoot weight in yield determination. [61] however, reported that shoot size contributed only $11 \%$ of the total seasonal yield variation, the remaining $89 \%$ being accounted for by the number of shoots. Seasonal yield variations mainly occur due to differences in shoot density [62]. However, later investigations [35] [56] hypothesized that shoot growth rate was the major component causing seasonal fluctuation in yield while shoot density was the major factor determining yield difference between varieties. In this study the genotype and environment interactions show that the yield components contribution to yield in any environment varies significantly with the genotype. The findings reported above are results of studies conducted in single site with the varying environmental factor being the climatic seasons.

Yield components' contribution to yield varied with genotype within the same environment and between environments (Table 8). This could explain the variation in yield stabilities across different environments. Similar results have been reported [14] [17] illustrating the variations in clonal growth response to temperatures across four sites within Kericho region. Findings from this study indicate that variations in tea response to weather parameters may apply even across locations with different climatic regimes. The results therefore suggest that not all yield components can be used for yield selection in all environments. Indeed, in Kangaita clonal yield selection would best be done using shoot density as a yield indicator while in Timbilil shoot growth rate would be the best selection indicator.

Variation in clonal yield components' response to environments explains the variability clonal yield response among environments. The interaction and the dominant component response determine the actual clonal yields realised in every location. Yield optimisation should therefore be targeted at the management practices that reduces the yield limiting factors and maximises the dominant responsive component e.g. sprinkler irrigation during periods of moisture stress to reduce soil water deficits and raise the relative humidity hence lowering the SVPD which is the main factor limiting growth in such conditions. Clonal selections will also have to be location specific. Clonal selection for universal planting will not always optimise yields across all locations. Yield modelling even for a single clone across all sites will at best be estimate not accurate. Perhaps this would explain the difficulty in modelling of yield predictions encountered in past works.

\subsection{Yield and Yield Components' Response to Weather}

All yield components studied (shoot growth rates, shoot dry weights and shoot densities), showed significant clonal variations in their sensitivity to the different environments. Generally, shoot growth rate increased with temperature across the locations while shoot dry weights varied significantly $(\mathrm{p} \leq 0.05)$ between sites but showed no response to temperature or vapour pressure deficit. All yield components gave significant $(p \leq 0.001)$ genotypic variations in their responses to the environment (Table 8). Yield components and weather trends presented in Table 4 and Table 5, respectively indicate general linear responses of yield components to weather parameters from low to high altitude (Kipkebe to Kericho). Shoot growth rates increase with increasing ambient temperatures across the sites, while shoot dry weights and shoot densities showed no apparent response to temperatures across the sites. Correlation analysis showed the same relationship but shoot density tended to reduce with rising ambient temperature. Across the three trial sites the temperatures tended to drop with increased rainfall leading to yield depression at Kangaita and Timbilil where ambient temperatures were lower. At Kipkebe however, lower rainfall did not depress yields as the temperatures remained warmer.

Correlation analysis however, show that the yield and individual yield component response to weather parameters vary significantly ( $\mathrm{p} \leq 0.05$ ) between locations (Table 9 ). These correlations explain the locational variation in the yield models above (Table 9). The results imply that it is not possible to give an accurate yield model 
Table 9. Effects of location on correlations of yield, yield components and weather parameters across three geographical regions of tea production.

\begin{tabular}{|c|c|c|c|c|c|c|c|}
\hline \multicolumn{2}{|c|}{ Location } & \multirow{2}{*}{$\begin{array}{c}\text { Temp } \\
-0.499^{* *}\end{array}$} & \multirow{2}{*}{$\begin{array}{c}\text { Rain } \\
-0.147\end{array}$} & \multirow{2}{*}{$\begin{array}{c}\mathrm{Rh} \\
-0.106\end{array}$} & \multirow{2}{*}{$\begin{array}{l}\text { Rdays } \\
-0.452^{* *}\end{array}$} & \multirow{2}{*}{$\begin{array}{c}\text { Svpd } \\
-0.270^{*}\end{array}$} & \multirow{2}{*}{$\begin{array}{c}\text { Tir } \\
-0.330^{* *}\end{array}$} \\
\hline & Yield & & & & & & \\
\hline & Swp & $0.718^{* *}$ & $-0.962^{* *}$ & $-0.990^{* *}$ & $-0.386^{* *}$ & $0.938^{* *}$ & $0.954^{* *}$ \\
\hline \multirow[t]{5}{*}{ Kangaita } & Sgr & $-0.669^{* *}$ & 0.201 & $0.325^{* *}$ & $-0.555^{* *}$ & $-0.751^{* *}$ & $-0.456^{* *}$ \\
\hline & Sd & $-0.293^{* * *}$ & $0.495^{* *}$ & $0.528^{* *}$ & 0.047 & $-0.603^{* *}$ & $-0.358^{* *}$ \\
\hline & Sdwt & $-0.305^{* *}$ & -0.210 & -0.063 & $-0.661^{* *}$ & $-0.239^{*}$ & 0.038 \\
\hline & Yield & $-0.665^{* *}$ & $0.281^{*}$ & $0.543^{* *}$ & $0.268^{*}$ & $-0.421^{* *}$ & $-0.516^{* *}$ \\
\hline & Swp & $0.343^{* *}$ & $-0.404^{* *}$ & $-0.341^{* *}$ & $-0.390^{* *}$ & $0.301^{*}$ & 0.173 \\
\hline \multirow[t]{5}{*}{ Kipkebe } & Sgr & 0.217 & $-0.471^{* *}$ & 0.009 & $-0.317^{* *}$ & -0.118 & -0.025 \\
\hline & Sd & $0.526^{* *}$ & $-0.590^{* *}$ & $-0.836^{* *}$ & $-0.432^{* *}$ & $-0.272^{*}$ & 0.217 \\
\hline & Sdwt & $0.407^{* *}$ & 0.047 & -0.211 & 0.140 & $-0.382^{* *}$ & $0.323^{*}$ \\
\hline & Yield & 0.208 & -0.163 & 0.124 & -0.008 & 0.060 & -0.025 \\
\hline & Swp & $0.808^{* *}$ & $-0.909^{* *}$ & $-0.997^{* *}$ & $-0.978^{* *}$ & $0.950^{* *}$ & $0.924^{* *}$ \\
\hline \multirow[t]{3}{*}{ Timbilil } & Sgr & 0.000 & 0.189 & $0.517^{* *}$ & $0.389^{* *}$ & $-0.273^{*}$ & $-0.286^{* *}$ \\
\hline & Sd & 0.087 & 0.064 & $0.407^{* *}$ & $0.266^{*}$ & -0.163 & -0.219 \\
\hline & Sdwt & $-0.222^{*}$ & $0.268^{*}$ & $0.602^{* *}$ & $0.448^{* *}$ & $-0.412^{* *}$ & $-0.499^{* *}$ \\
\hline
\end{tabular}

*Significant at $0.05 ;{ }^{* *}$ Significant at 0.01 ; Yld = Annual yield; Sgr = shoot growth rate; Sd = Shoot density; Sdwt = Shoot dry weight; Swp = Shoot water potential; Temp = Ambient temperature; Rain = Annual rainfall; Rh = Relative humidity; Rdays = Rain days; Svpd = Saturated vapour pressure deficit; Tir = Total incident radiation.

for yield prediction across all environments for all tea genotypes and that the general response of yield and yield component across environments is not universal.

\section{Conclusion}

Soil chemical and physical parameters varied between sites, but were suitable for tea growing. Yield components contribution to yield varied with location. The response of tea yield components to weather factors also varied with location. Genotype yields and yield components varied significantly in their response to environment, variations in correlations between yield and yield components indicate that the response of tea yield components to weather factors varied with location. These variations give rise to the yield variability between locations and between genotypes. Shoot density and shoot growth rates were more closely related to yields only in Kangaita and Timbilil, and might therefore be used as yield selection indicators in Kangaita and Timbilil. Yield components may not be used universally for clonal selection. Genotypes selected in any one location may perform optimally in another location. Selected clones should therefore be subjected to testing before adoption for commercial planting in another location.

\section{Acknowledgements}

The authors wish to thank Kenya Tea Development Authority (KTDA) and Kipkebe Tea Company Ltd. For providing trial sites, the Inter-University Council of East Africa: Lake Victoria Research (VicRes) Initiative and National Council of Science and Technology (NACOSTI) for funding of the study and the staff of Crop Environment and Physiology section, and Kangaita station of the Tea research Institute for their assistance in data collection. This paper is published with the approval of the Director of the Tea Research Institute of Kenya. 


\section{References}

[1] Bokuchava, M.A. and Skobelava, N.I. (1969) The Chemistry and Biochemistry of Tea and Tea Manufacture. Advances in Food Research, 17, 215-292. http://dx.doi.org/10.1016/S0065-2628(08)60311-0

[2] Hara, Y., Liu, S.J., Wickermasinghe, R.L. and Yamanishi, T. (1995) Special Issue on Tea. Food Review, International, 11, 371-545

[3] TBK (2011) Tea Board of Kenya Statistics. Tea Board of Kenya, Nairobi, Kenya.

[4] Owuor, P.O. (1999) Tea in East Africa (Kenya, Uganda, Tanzania). In: Jain, N.K., Ed., Global Advances in Tea Science, New Age International Ltd., New Delhi, India, 171-188.

[5] (2002) Tea Growers Hand Book. 5th Edition, Tea Research Foundation of Kenya, Kericho.

[6] Owuor, P.O., Obanda, M., Nyirenda, H.E. and Mandala, W.L. (2008) Influence of Region of Production on Clonal Black Tea Characteristics. Food Chemistry, 108, 263-271. http://dx.doi.org/10.1016/j.foodchem.2007.09.017

[7] Eden, T. (1931) Studies in the Yield of Tea I. The Experimental Errors of Field Experiments with Tea. Journal of Agricultural Science, 21, 547-573. http://dx.doi.org/10.1017/S0021859600088511

[8] Squire, G.R. (1979) Weather, Physiology and Seasonality of Tea (Camellia sinensis) Yield in Malawi. Experimental Agriculture, 15, 321-330. http://dx.doi.org/10.1017/S0014479700012953

[9] Tanton, T.W. (1992) Tea Crop Physiology. In: Willson, K.C. and Clifford, M., Eds., Tea: Cultivation to Consumption, Chapman and Hall, London, 173-199. http://dx.doi.org/10.1007/978-94-011-2326-6_6

[10] Owuor, P.O. (1990) Variations of Tea Quality Parameters: Response of Black Commercial Seedling Tea to Time of the Year at Nyambene Hills. Preliminary Results. Tea, 11, 5-7.

[11] Othieno, C.O., Stephens, W. and Carr, M.K.V. (1992) Yield Variability at the Tea Research Foundation of Kenya, Agriculture and Forestry Journal, 61, 237-252.

[12] Owuor, P.O. (1994) Clonal Variations in the Response of Black Tea (Camellia sinensis (L.)) Quality Qarameters to Time of the Year in the Western Kenya Highlands. Tropical Science, 34, 225-230.

[13] Kwach, B.O., Kamau, D.M., Msomba; S.W., Muhoza, C. and Owuor, P.O. (2014) Effects of Location of Production, Nitrogenous Fertilizer Rates and Plucking Intervals on Clone TRFK 6/8 Tea in East Africa: II. Mature Leaf Nutrients. International Journal of Tea Science, 10, 25-40

[14] Ng'etich, W.K. and Stephens, W. (2001) Responses of Tea to Environment in Kenya. II. Genotype × Environment Interactions for Total Dry Matter Production and Yield. Experimental Agriculture, 37, 333-342.

[15] Obaga, S.O., Squire, G.R. and Lang'at, J.K. (1988) Altitude Temperature and Growth of Tea Shoots. Tea, 9, $28-33$.

[16] Obaga, S.M.O., Othieno, C.O. and Lang'at, J.K. (1989) Observations on the Effects of Altitude on The Yield Attributes of Some Tea Clones-Growth and Density of Tea Shoots. Tea, 10, 73-79

[17] Squire, G.R., Obaga, S.M.O. and Othieno, C.O. (1993) Altitude, Temperatures and Shoot Production of Tea in the Kenyan Highlands. Experimental Agriculture, 29, 107-120. http://dx.doi.org/10.1017/S0014479700020457

[18] Wachira, F., Ng'etich, W., Omolo, J. and Mamati, G. (2002) Genotype \& Environment Interactions for Tea Yields. Euphytica, 127, 289-296. http://dx.doi.org/10.1023/A:1020273616349

[19] Ng'etich, W.K., Stephens, W. and Othieno, C.O. (2001) Responses of Tea to Environment in Kenya. 3. Yield and Yield Distribution. Experimental Agriculture, 37, 361-372. http://dx.doi.org/10.1017/s0014479701003076

[20] Msomba, S.W., Kamau, D.M., Uwimana, M.A., Muhoza, C. and Owuor, P.O. (2014) Effects of Location of Production, Nitrogenous Fertilizer Rates and Plucking Intervals on Clone TRFK 6/8 Tea in East Africa: I. Yields. International Journal of Tea Science, 10, 14-24.

[21] Cherotich, L., Kamunya, S.M., Alakonya, A., Msomba, S.W., Uwimanna, M.A. and Owuor, P.O. (2013) Characterization of 20 Clones of Tea (Camellia Sinensis (L.) O. Kuntze) Using ISSR and SSR Markers. Agricultural Science Research Journal, 3, 292-302.

[22] Cherotich, L., Kamunya, S.M., Alakonya, A., Msomba, S.W., Uwimanna, M.A. and Owuor, P.O. (2014) Genotypic Stability and Adaptability of Tea Cultivars in Relation to Catechin Levels across Four Environments. Tea, 35, 8-16.

[23] Kwach, B.O., Owuor, P.O., Kamau, D.M., Msomba, S.W. and Uwimana, M.A. (2016) Variations in the Precursors of Plain Black Tea Quality Parameters Due to Location of Production and Nitrogen Fertilizer Rates in Eastern African Clonal Tea Leaves. Experimental Agriculture, 52, 266-278.

[24] Okal, A.W., Owuor, P.O., Kamau, D.M. and Mang’uro, L.O.A. (2012) Effects of Production Location and Plucking Interval on the Fatty Acids Concentration of Clonal Tea. Food Science and Technology Research, 18, 351-356. http://dx.doi.org/10.3136/fstr.18.351

[25] Okal, A.W., Owuor, P.O., Kamau, D.M. and Mang'uro, L.O.A. (2012) Variations of Fatty Acids Levels in Young 
Shoots of Clonal Tea with Location of Production and Nitrogenous Fertilizer Rates in the Kenya Highlands. Journal of Agricultural Science and Technology, 14, 1543-1554.

[26] Owuor, P.O., Kamau, D.M., Kamunya, S.M., Msomba, S.W., Uwimana, M.A., Okal, A.W. and Kwach, B.O. (2011) Effects of Genotype, Environment and Management on Yields and Quality of Black Tea. In: Lichtfouse, E., Ed., Genetics, Biofuels and Local Farming Systems: Sustainable Agriculture Reviews, Vol. 7, Springer, Heidelberg, 277-307. http://dx.doi.org/10.1007/978-94-007-1521-9_10

[27] Owuor, P.O., Okal, A.W., Kamau, D.M., Msomba, S.W., Uwimana, M.A. and Kamunya, S.M. (2013) Influence of Nitrogen Fertilizer Rates and Harvesting Intervals on Clonal Tea Green Leaf Fatty Acids Levels in the Lake Victoria Basin of Kenya. Journal of Agriculture, Food and Environment, 11, 667-674.

[28] Owuor, P.O., Obaga, S.O. and Othieno, C.O. (1990) The Effects of Altitude on the Chemical Composition of Black Tea. Journal of Science Food and Agriculture, 50, 9-17. http://dx.doi.org/10.1002/jsfa.2740500103

[29] Owuor, P.O., Wachira, F.N. and Ng'etich, W.K. (2010) Influence of Region of Production on Relative Clonal Plain Tea Quality Parameters in Kenya. Food Chemistry, 119, 1168-1174. http://dx.doi.org/10.1016/j.foodchem.2009.08.032

[30] Owuor, P.O., Kamau, D.M., Kamunya, S.M., Msomba, S.W., Jondiko, E.O. and Uwimana, M.A. (2013) The Response of Clone BBK 35 Tea to Nitrogen Fertilizer Rates and Harvesting Intervals in the Lake Victoria Basin of Kenya. Journal of Agriculture, Food and Environment, 11, 757-763.

[31] Balasuriya, J. (1999) Shoot Population Density and Shoot Weight of Clonal Tea (Camellia Sinensis) at Different Altitudes in Sri Lanka. European Journal of Agronomy, 11, 123-130. http://dx.doi.org/10.1016/S1161-0301(99)00024-6

[32] Anandacoomaraswamy, A., De Costa, W.A.J.M., Shyamalie, H.W. and Campbell, G.S. (2000) Factors Controlling Transpiration of Mature Field-Grown Tea and Its Relationship with Yield. Agricultural and Forest Meteorology, 103, 375-386. http://dx.doi.org/10.1016/S0168-1923(00)00134-9

[33] Mahanta, P.K., Baruah, S., Owuor, P.O. and Murai, T. (1988) Flavour Volatiles of Assam Black Teas Manufactured from Different Plucking Standards and Orthodox Teas Manufactured from Different Altitudes of Darjeeling. Journal of the Science of Food and Agriculture, 45, 317-324. http://dx.doi.org/10.1002/jsfa.2740450405

[34] Tanton, T.W. (1979) Some Factors Limiting Yields of Tea (Camellia sinensis). Experimental Agriculture, 15, $187-191$. http://dx.doi.org/10.1017/S0014479700000594

[35] Odhiambo, H.O., Nyabundi, J.O. and Chweya, J. (1993) Effects of Soil Moisture and Vapour Pressure Deficits on Shoot Growth and Yield of Tea in The Kenya Highlands. Experimental Agriculture, 29, 341-350. http://dx.doi.org/10.1017/S0014479700020901

[36] Wickramaratne, M.R.T. (1981) Genotype-Environmental Interaction in Tea (Camellia sinensis L.) and Their Implications in Tea Breeding Selections. The Journal of Agricultural Science, 96, 471-478. http://dx.doi.org/10.1017/S0021859600066259

[37] Tea Board of Kenya (2005) Annual Technical Report. Tea Research Foundation of Kenya. Tea Board of Kenya, Nairobi.

[38] Cooper, J.D. (1979) Water Use of a Tea Estate from Soil Moisture Measurements. East African Agriculture and Forestry Journal, 43, 102-121.

[39] Gee, W. and Baader, J.W. (1986) Particle Size Analysis. In: Klute, A., Ed., Methods of Soil Analysis: I: Physical and Mineralogical Methods, Agronomy Services, No. 9. American Society of Agronomy, Inc., Soil Science Society of America, Inc., Madison, 384-411.

[40] Mwebesa, M. (1978) Atmospheric Moisture and Clouds. In: Mwebesa, M., Ed., Basic Meteorology, East African Literature Bureau, Nairobi, 69-76.

[41] List, J.R. (1949) Hygrometric and Physchrometric Tables. In: List, J.R., Ed., Smithsonian Meteorological Tables, Vol. 114, 6th Edition, 1971 Reprint, Section VII, Smithsonian Institution Press, Washington DC, 347-385.

[42] Odhiambo, H.O. (1989) Nitrogen Rates and Plucking Frequency on Tea: The Effect of Plucking Frequency and Nitrogenous Fertilizer Rates on Yield and Yield Components of Tea (Camellia sinensis (L.) O. Kuntze) in Kenya. Tea, 10, 90-96.

[43] Scholander, P.F., Hammer, E.D., Hemmingsen, E.A. and Hammel, H.T. (1965) Sap Pressure in Vascular Plants. Science, 148, 333-346.

[44] Jaetzold, R., Schmidt, H., Hornetz, B. and Shisanya, C. (2010) Farm Management Handbook of Kenya, Vol. II, Natural Conditions and Farm Management Information. 2nd Edition, PART II/B Central Kenya, Subparts B1 and B2 Central and Rift Valley Province Middle and Ministry of Agriculture, Kenya, in Cooperation with the German Agency for Technical Cooperation (GTZ), Nairobi.

[45] Othieno, C.O. (1992) Soils. In: Willson, K.C. and Clifford, M.N., Eds., Tea: Cultivation to Consumption, Chapman and Hall, London, 137-171. http://dx.doi.org/10.1007/978-94-011-2326-6_5 
[46] Ng'etich, W.K., Stephens, W. and Othieno, C.O. (1995) Clonal Tea Response to Altitude in Kericho. I. Site Description. Tea, 16, 78-84.

[47] Kebeney, S.J., Kamau, D.M., Othieno, C.O., Ng'etich, W.K. and Owuor, P.O. (2010) Changes in Soil Chemical and Leaf Nutrient Content in Tea Due to Nitrogen Fertiliser Rates and Application Intervals. Tea, 31, 22-37.

[48] Ng'etich, W.K., Stephens, W. and Othieno, C.O. (1995) Clonal Tea Response to Altitude in Kericho. 1. Weather, Climate Analysis and Soil Water Deficits. Tea, 16, 85-98.

[49] Stephens, W., Othieno, C.O. and Carr, M.K.V. (1992) Climate and Weather Variability at Tea Research Foundation of Kenya. Agricultural and Forest Meteorology, 61, 219-235. http://dx.doi.org/10.1016/0168-1923(92)90051-5

[50] Acland, J.D. (1989) Tea. In: Acland, J.D., Ed., East African Crops, Longman, London, 208-222.

[51] Bonheure, D. (1990) Tea. In: Coste, R., Ed., The Tropical Agriculturalist, Technical Centre for Agriculture and Rural Cooperation (CTA), Macmillan, London, 64-68.

[52] Williams, E.N.D. (1971) Investigations into Certain Aspects of Water Stress in Tea. In: Carr, M.K.V. and Carr, S., Eds., Water and the Tea Plant, Tea Research Institute of East Africa, Kericho, 79-87.

[53] Tanton, T.W. (1982) Environmental Factors Affecting the Yield of Tea (Camellia sinensis). II. Effects of Soil Temperature, Day Length and Dry Air. Experimental Agriculture, 18, 53-63. http://dx.doi.org/10.1017/S0014479700013429

[54] Obaga S.M.O. and Ng’etich, W.K. (1989) Thermal Time and Growth of Shoots of Tea Clones. Tea, 10, 8-14.

[55] Burgess, P.J. and Carr, M.K.V. (1997) Response of Young Tea (Camellia Sinensis) Clones to Drought and Temperature. Experimental Agriculture, 33, 367-383. http://dx.doi.org/10.1017/S0014479797003050

[56] Stephens, W. and Carr, M.K.V. (1990) Seasonal and Clonal Differences Shoot Extension Rates and Numbers in Tea (Camellia sinensis). Experimental Agriculture, 26, 83-98. http://dx.doi.org/10.1017/S001447970001543X

[57] Odhiambo, H.O. (1991) The Effects of Seasonal Changes on Soil Moisture, Atmospheric Humidity, Ambient Temperature and Radiation on Shoot Water Status, Growth and Yield of Four Clones of Tea (Camellia sinensis L.). Msc. Thesis, University of Nairobi, Nairobi.

[58] Kamunya, S.M., Msomba, S., Makola, L., Korir, R., Kamau, P., Wachira, F.N. and Ndunguru, B.J. (2012) Performance and Genetic Stability for Yield and Quality of Improved Tea Clones in Kenya and Tanzania. Tea, 33, 5-17.

[59] Burgess, P.J. (1992) Responses of Tea Clones to Drought in Southern Tanzania. PhD Thesis, Silsoe College, Cranfield University, Cranfield.

[60] Ellis, R.T. and Grice, W.T. (1976) Plucking Policy and Techniques. Quarterly Newsletter. Tea Research Foundation of Central Africa, 41, 3-14.

[61] Tanton, T.W. (1981) Growth and Yield of the Tea Bush. Experimental Agriculture, 17, 177-191. http://dx.doi.org/10.1017/S0014479700011698

[62] Kulasegaram, S. and Kathiravetpillai, A. (1974) The Influence of Climate and Gas on Yield of 4 Tea Clones. Tea Quarterly, 44, 100-112. 